\title{
Electronic Commerce Use in Small and Medium-Sized Enterprises:
}

Some Evidence from Northeastern United States

\author{
Fahri Karakaya and Omar Khalil \\ University of Massachusetts Dartmouth
}

\begin{abstract}
The Internet and Electronic Commerce (EC) related practices were surveyed in ninety-four small and mid-sized enterprises (SMEs) from a region of the Northeastern United States. Only 6.3 percent of the firms' sales was found to be attributable to e-commerce business. The results suggest some relationships of a firm's sales and profitability on one hand and the firm's Internet use on the other hand. Firms that rated their profitability and sales levels to be higher seem to have higher use of the Internet to gather distributor and vendor information, to conduct online purchasing, and to promote their products online. The majority of the firms surveyed tend to use e-mail to a great extent for communications internally among employees and externally with customers, vendors and distributors. Higher levels of e-mail usage for internal and external communications tend to associate with higher levels of reported sales and profitability. However, the findings suggest that most of the SMEs do not employ the Internet to its full capacity. In order for SMEs to advance their EC activities they need to develop their own EC strategies and to secure the managerial, human, financial, and technological resources to effectively implement them.
\end{abstract}

\section{INTRODUCTION}

The ever growing Internet use and EC activities are evident in the experts' and researchers' statistics and estimates. For example, the number of Internet users in 1997 was 170 million worldwide, and this number is expected to grow to approximately 350 million by 2005 (O'Shea, 1999). Currently there are 148.7 million Internet users in North America, 86.6 million users in Western Europe, 57.6 million users in Asia Pacific, 10.8 million users in South/Central America, 9.5 million users in Eastern Europe, and 7.5 million users in Middle East/Africa. 
Similarly, the number of publicly accessible Web pages is expected to grow from 800 million today to 8 billion by 2002 (Moeller 1999).

Further, EC is growing exponentially. Back in 1997, the global EC was estimated at $\$ 10$ billion, exceeded $\$ 13$ billion in 1998 , but is predicted to rise to $\$ 200-300$ billion by 2002 (Morphett, 1999), and to increase to $\$ 3$ trillion by 2003 (Aaron, Maurizio, and Skillen, 1999; O'Shea, 1999). In the U.S., 40 percent of U.S. households are now online and 40 million consumers have shopped online in the year 2000. It is also expected that by the year 2003, there will be over 60 million shoppers online. (Cyberdialogue, 2000). Forrester Research Inc. forecasts that by 2002, Internet commerce among U.S. businesses alone (U.S. business-to-business Internet commerce) will be $\$ 327$ billion up from year 2000's estimate of $\$ 17$ billion. The business-to-business portion of EC is estimated to be 78 percent of the total dollar value of electronic transactions, and it's estimated that the consumer ecommerce will grow to $\$ 108$ billion in 2003 (Hof 1999).

Therefore, EC has been accepted as a bona fide business practice in the commercial world (Davis \& Garcia-Sierra, 1999). Industry Week (1999) quotes the head of Motorola's electronic commerce department as saying; "Anyone not making the change to Web-based commerce within the next year would probably be locked out of their business for good." While many businesses, small and med-sized enterprises (SMEs) in particular, have web sites and claim to practice EC, little is known on how much they use the Internet to conduct business online, how extensively they employ the many E-Commerce tools that are available, whether the businesses that employ E-Commerce tools are more successful than the ones that do not, and whether firm size influences the extent of employing of e-commerce tools. With this in mind, this study was designed to explore the extent of EC use by SMEs located in a region of the Northeastern United States.

\section{BACKGROUND}

The Web is poised to become the medium by which companies buy, trade, make contacts, exchange data and information, discuss designs, and locate companies. Although EC can be defined from different perspectives (e.g., communication, business process, service and online), perhaps a useful way to view it is to link it to trading. EC is trading by means of new communication technology. It includes all aspects of trading such as commercial market making, making, ordering, supply chain management and the transfer of money (Garnett and Skevington, 1999).

EC fosters building better relationships among customers, producers, and suppliers. Its implementation harnesses networked resources to further the exchange of business transactions in a more efficient and cost effective manner (Aaron, Maurizio, and Skillen, 1999). It contributes to economic efficiency in such ways as shrinking distances and timescale, lowering distribution and transaction costs, 
speeding product development, disseminating more information to buyers and sellers, and enlarging customer choice and supplier reach (Levis, 1996).

As a consequence of EC growth, small and medium-sized enterprises (SMEs) face pressures from supply chain reorganization that exclude them or reduce their role to sub-contracting, and from the closure of independent retailers (Rhodes \& Carter, 1998). Because online competitors are forcing customized responses to customers' demands, SMEs must provide services that eclipse products as the source customer value, match production to real-time customer demand, and float prices with current market conditions. Designed for efficiency in an environment of slow change, SMEs' business practices must be dismantled and rebuilt to support mass customization, open finance, and business process outsourcing (McCarthy, 1999).

Fortunately, the Internet is a potential force in democratization of capitalism, and offers SMEs and consumers dramatic new possibilities in the global marketplace (Quelch \& Klein, 1996). Potential EC benefits for SMEs include increased research capabilities, more efficient sourcing and purchasing, reduced administration time and expense, more effective data exchanges, increased visibility and sales, and use as a customer service tool (Davis \& Garcia-Sierra, 1999).

SMEs are expected to recognize and seek strategic benefits with EC, and to invest heavily in web technologies and in web-based systems. However, the development of Internet-based strategies by SMEs to meet the challenge of large firms depends on the internal firm dynamics, including willingness-or resistance-to undertake major changes in practice and the external contexts, particularly the financia1, technological, political and regulatory environments (Rhodes \& Carter, 1998). Future plans and policies that aim at advancing SMEs adoption and practice of EC must depend on accumulated empirical evidence on the current EC practices, problems, and potentials. This investigation is designed to profile EC practice of a number of SMEs located in a region of the Northeastern United States.

\section{METHOD}

In order to profile EC practice among SMEs, a survey was designed in cooperation with the five area business executives and pretested. After minor modifications, the survey along with a personalized letter and a return envelope were mailed to 490 firms located in a region of the Northeastern United States in May 2000.

The firms were selected using a stratified sampling procedure that employed the area zip codes. The cover letters were directed at the contact persons listed in the database asking them to route the survey to the individual(s) responsible for ecommerce activities. Ninety-four companies responded to the survey (19\%). 


\subsection{Demographics of the Responding Firms:}

Fifty-four percent of the responding firms were manufacturers, $20 \%$ service firms, $10 \%$ distributors, $8 \%$ retailers, and $8 \%$ others. The responding companies indicate that on average only 6.3 percent of their sales was attributable to ecommerce business. It is important to note that 58 percent of the businesses (50 organizations) indicates that zero percent of their sales was attributable to ecommerce. Only five companies attribute 25 percent or more of their sales to ecommerce. On average, the responding firms have engaged on e-commerce for approximately 17 months (ranging from zero to five years). The responding firms also report that their sales and profits have been in the range of very good and good (mean ratings of 3.6 and 3.46 respectively, measured as $3=$ good and $4=$ very good). The average size of the responding businesses was 127 employees ranging from a minimum of 0 employee to maximum of 1954 employees.

\section{RESULTS}

The analysis of the 94 area companies indicates that many businesses have access to the Internet and many are already doing business online. However, most businesses use the Internet on a limited scale and need assistance in a variety of technical and non-technical areas. Ninety two percent of the firms has access to the Internet and 73 percent has web sites. However, on average, only one out of four companies $(25 \%)$ utilize the Internet regularly in conducting business, including, online promotion, online sales and purchase, online customer service, and gathering online marketing, vendor, and distributor data. Overall, most of the businesses surveyed have Internet presence in order to provide information about their products and services.

\subsection{Internet Use and Company profitability and Sales}

The Internet usage varies among the responding companies. While some are heavy Internet users others use the Internet on a limited basis. Table 1 shows the types of Internet use and the rating of company profits by the respondents. As one may note, despite the fact that the majority of the firms have web sites, only a small percent of them utilize the advanced Internet tools. Most of the activities listed in Table 1 are "only occasional usage."

Analysis of variance (ANOVA) was performed to examine whether the Internet usage varies by company profitability and company sales levels. The respondents rated their profitability and sales levels on a five-point scale, ranging from very poor to excellent. Similarly, the respondents rated their various types of Internet usage, ranging from always to never use. In performing the ANOVA, the Internet usage variables were employed as multi dichotomous while company profitability and sales 
were treated as dependent variables. The means in Table 1 Indicate the Internet usage activities and one could assess the extent of these activities from the means.

Two of the seven variables shown in Table 1 show statistically significant relationship between company profitability levels and Internet usage. The companies that always gather distributor information through the Internet rated their profitability levels higher than the respondents who do the same occasionally, never, and almost always (mean $=5.0$ vs. $3.33,3.52$, and 3.67 respectively). Companies that always conduct online purchase transactions rated themselves more profitable than the companies that perform online purchases almost always, occasionally, and never (mean $=4.5$ vs. $3.11,3.41$ and 3.44 respectively).

In addition, post hoc tests (Duncan's Multiple Range Test) indicate that there are other differences among the firms with different profitability levels. Those firms that always use the Internet to gather vendor information are more profitable than the firms who use the Internet occasionally doing the same activity (mean $=4.40$ vs. 3.34 respectively). Similarly, firms using the Internet to promote their products always rated themselves as more profitable than the firms never using the Internet for promotion purposes (mean $=4.09$ vs. 3.21 respectively).

\begin{tabular}{|l|c|c|c|c|}
\hline \multicolumn{1}{|c|}{ Internet Use } & Mean & F-Value & P-Value & Post Hoc Test \\
\hline $\begin{array}{l}\text { Gather Marketing } \\
\text { Research Data }\end{array}$ & 1.18 & 1.14 & .34 & ------ \\
\hline $\begin{array}{l}\text { Gather Vendor } \\
\text { Information }\end{array}$ & 1.24 & 1.87 & .14 & $1 \& 3$ \\
\hline $\begin{array}{l}\text { Gather Distributor } \\
\text { Information }\end{array}$ & 1.00 & 2.94 & .03 & $0,1,2 \& 3^{*}$ \\
\hline $\begin{array}{l}\text { Promotion through } \\
\text { Internet }\end{array}$ & 1.26 & 2.00 & .12 & $0 \& 3$ \\
\hline $\begin{array}{l}\text { Conduct Online Sales } \\
\text { transactions }\end{array}$ & 0.78 & 0.98 & .41 & -------- \\
\hline $\begin{array}{l}\text { Conduct Online } \\
\text { Purchases }\end{array}$ & 0.85 & 2.64 & .05 & $0,1,2 \& 3$ \\
\hline $\begin{array}{l}\text { Conduct Online } \\
\text { Customer Surveys }\end{array}$ & 0.44 & 1.13 & .34 & ------- \\
\hline
\end{tabular}

Scale: Internet use activities were measured as: Never $=0$; occasionally $=1$; almost always $=2$, and always $=3$. Profitability variable was measured on a five-point scale as Excellent, Very Good, Good, poor, Very Poor.

*Should be read as there is a difference in company profits between firms always gathering distributor information and companies gathering distributor information almost always, occasionally, and never.

Table 1. Types of Internet Use by RespondingFirms and Relationship with Company Profits

Table 2 shows the ANOVA and post hoc test results for company sales as rated by the responding firms. As it was the case with company profitability, the firms that use the Internet extensively (always) to gather distributor information rate their 
sales higher than the companies that never or occasionally gather distributor information through Internet (mean=5 vs. 3.31, 3.60 respectively). The Duncan's Multiple Range Test also showed that there is a statistically significant difference in the sales levels of companies that utilize the Internet in conducting customer surveys occasionally (mean=4.06) and never (mean=3.41).

While the ANOVA results were statistically insignificant, promotion through Internet and conducting online purchases were found to be related to company sales levels in the post hoc tests performed. Firms that consider themselves as using the Internet always (mean $=4.30$ ) for promotion rate their sales levels higher than the firms that utilize the Internet occasionally (mean=3.53) or never (mean=3.38) for promotion. Similarly, The firms that always use the Internet for online purchasing rate themselves as having higher sales levels than firms conducting online purchases occasionally and never (mean $=4.5$ vs. $3.60,3.51$ respectively).

\begin{tabular}{|c|c|c|c|c|}
\hline Internet Use & Mean & F-Value & P-Value & Post Hoc Test \\
\hline $\begin{array}{l}\text { Gather Marketing } \\
\text { Research Data }\end{array}$ & 1.18 & 0.74 & .53 & ---- \\
\hline $\begin{array}{l}\text { Gather Vendor } \\
\text { Information }\end{array}$ & 1.24 & 1.32 & .27 & $\cdots-$ \\
\hline $\begin{array}{l}\text { Gather Distributor } \\
\text { Information }\end{array}$ & 1.00 & 3.27 & .03 & $0,1 \& 3^{*}$ \\
\hline $\begin{array}{l}\text { Promotion through } \\
\text { Internet }\end{array}$ & 1.26 & 2.08 & .10 & $0,1 \& 3$ \\
\hline $\begin{array}{l}\text { Conduct Online Sales } \\
\text { transactions }\end{array}$ & 0.78 & 1.24 & .30 & - . - - - \\
\hline $\begin{array}{l}\text { Conduct Online } \\
\text { Purchases }\end{array}$ & 0.85 & 1.89 & .13 & $0,2 \& 3$ \\
\hline $\begin{array}{l}\text { Conduct Online } \\
\text { Customer Surveys }\end{array}$ & 0.44 & 2.75 & .05 & $0 \& 1$ \\
\hline
\end{tabular}

Scale: Internet use activities were measured as never $=0$; occasionally $=1$; almost always $=2$, and always $=3$. Sales variable was measured on a five-point scale as Excellent, Very Good, Good, poor, Very Poor.

* Should be read as: there is a difference between firms gathering distributor information through Internet always and occasionally and never.

Table 2. Types of Internet Use by RespondingFirms and Relationship with Company Sales

\subsection{E-Mail Usage and Company Profitability and Sales:}

The vast majority of the responding firms use e-mail for one reason or another. More specifically:

- 72 percent use e-mail to communicate within their organizations,

- 78 percent use e-mail to communicate with vendors,

- 75 percent use e-mail to communicate with distributors, and

- 85 percent use e-mail to communicate with customers. 
Indeed, e-mail usage appears to be the most Internet activity utilized by companies. One respondent commented "The first thing I do when I start work in the morning is to check my e-mail." To examine the relationship between the type of e-mail usage and company profitability and sales, ANOVA and post hoc tests (Duncan's Multiple Range Tests) were performed. The results indicate there are statistically significant relationships (see Table 3). Companies that use e-mail to communicate internally always, almost always, and occasionally rate themselves as more profitable than the firms that never use e-mail (mean=4.0; 3.56; 3.71 vs. 3.03). In other words, those firms that utilize e-mail more frequently to communicate with their employees rate themselves as more profitable compared to the ones that never use e-mail to communicate internally. Firms using e-mail to communicate with distributors always rate themselves as more profitable compared to the firms communicating with distributors through e-mail occasionally or never (mean=4.60 vs. $3.31,3.35$ respectively). Similarly, companies that use e-mail always, almost always, and occasionally to communicate with customers rate their profitability levels higher than the ones that never use e-mail to communicate with distributors (mean $=4.00 ; 3.54 ; 3.50$ vs. 2.72 respectively).

\begin{tabular}{|l|c|c|c|c|}
\hline \multicolumn{1}{|c|}{ Internet Use } & Mean & F-Value & P-Value & Post Hoc Tests \\
\hline $\begin{array}{l}\text { Use E-mail to } \\
\text { communicate within } \\
\text { organization }\end{array}$ & 1.31 & 4.26 & .00 & $0 \& 1,2,3^{*}$ \\
\hline $\begin{array}{l}\text { Use E-mail to } \\
\text { communicate with } \\
\text { vendors }\end{array}$ & 1.22 & 1.28 & .29 & ------ \\
\hline $\begin{array}{l}\text { Use E-mail to } \\
\text { communicate with } \\
\text { distributors }\end{array}$ & 1.10 & 3.03 & .03 & $3 \& 0,1$ \\
\hline $\begin{array}{l}\text { Use E-mail to } \\
\text { communicate } \\
\text { customers }\end{array}$ & 1.32 & 3.15 & .03 & $3 \& 0,1,2$ \\
\hline
\end{tabular}

Usage of E-mail was measured as on a four point scale as: Never $=0$; occasionally $=1$; almost always $=2$, and always $=3$

* Should be read as there is a statistically significant difference in company profits between firms never using e-mail to communicate within their organization and using e-mail occasionally, almost always, always to communicate within the organization.

Table 3. Types of E-Mail Use by Responding Firms and Relationship with Company Profits

The examination of company sales levels as related to type of e-mail use shows that all five types of e-mail use are related to company sales (see Table 4). Firms that always use e-mail to communicate within the organization have higher sales levels than those that never use e-mail in communicating within the organization (mean $=4.20$ vs. 3.27 respectively). Similarly, companies using e-mail almost always to communicate with vendors rate their sales higher than the ones who don't (mean $=4.00$ vs. 3.16 respectively). Firms that use e-mail always to communicate with distributors rate their sales higher than the ones who use e-mail occasionally or 
never to do the same (4.60 vs. $3.50,3.30$ respectively). Firms that utilize e-mail almost always to communicate with distributors also rate their sales higher than the firms who don't (mean=4.00 vs. 3.30). In examining the relationship between sales and the level of communication with customers, the ANOVA showed only a weak relationship exists $(\mathrm{p}=.059)$. The post hoc tests indicate that firms using e-mail always to communicate with customers

have higher sales levels than the ones that use e-mail occasionally or never (mean=4.22 vs. $3.43,3.27$ ).

\begin{tabular}{|l|c|c|c|c|}
\hline \multicolumn{1}{|c|}{ Internet Use } & Mean & F-Value & P-Value & Post Hoc Tests \\
\hline $\begin{array}{l}\text { Use E-mail to } \\
\text { communicate within } \\
\text { organization }\end{array}$ & 1.31 & 3.57 & .02 & $0 \& 3^{*}$ \\
\hline $\begin{array}{l}\text { Use E-mail to } \\
\text { communicate with vendors }\end{array}$ & 1.22 & 3.01 & .04 & $0 \& 2$ \\
\hline $\begin{array}{l}\text { Use E-mail to } \\
\text { communicate with } \\
\text { distributors }\end{array}$ & 1.10 & 3.94 & .01 & $3 \& 0,1$ and $2 \& 0$ \\
\hline $\begin{array}{l}\text { Use E-mail to } \\
\text { communicate customers }\end{array}$ & 1.32 & 2.58 & .06 & $3 \& 0,1$ \\
\hline
\end{tabular}

Table 4 continued.

E-mail usage was measured as on a four point scale as: Never=0; occasionally=1; almost always $=2$, and always $=3$

* Should be read as there is a statistically significant difference in company sales between firms never using e-mail to communicate within their organization and the firms using e-mail always to communicate within the organization.

Table 4. Types of E-mail Use by Responding Firms and Relationship with Company Sales

\subsection{Internet Use and Company profitability and Sales}

To examine the relationship between company size and web site contents, one would expect that larger firms would have more elaborate or comprehensive web sites. Most of the companies reported to have web-sites sites include company and product information (over 90\%). However, Only 17 percent of the firms have stock/inventory status of their products and 35 percent of the firms have online sales transaction capabilities on their web sites. While these two web functions are important in business operations, they require technical know how and are costly to integrate into web sites. Therefore, one would expect that larger companies to have these and other costly tools such as interactive customer service software. Table 5 shows the means of the companies in terms of the number of employees and whether they differ or not. Three of the tested nine web site content variables through t-tests differ between the relatively large and relatively small size firms. The average size of the firms with online catalogs on their web sites is 160 employees. This compares to companies with average employee size of 128 employees having no online catalogs. Similarly, relatively larger companies disclose company financial data on 
their web sites (average size of employees 483 vs. 135). However, one should interpret this with caution since only seven percent of the companies have this information available on their web sites. The third variable that was statistically significant was "links to other company web sites (e.g., suppliers, distributors or customers). Compared to the relatively smaller size firms, the web sites of the relatively larger firms contain more links to other sites.

\begin{tabular}{|l|c|c|c|c|c|}
\hline & $\begin{array}{c}\text { Presence } \\
\text { of } \\
\text { Content }\end{array}$ & \multicolumn{2}{|c|}{$\begin{array}{c}\text { Company Size } \\
\text { (Mean Number of } \\
\text { Employees) }\end{array}$} & T-Stats. & $\begin{array}{c}\text { Ssignifi- } \\
\text { cance } \\
\text { Level }\end{array}$ \\
\hline Web Page Content & $\%$ & Yes & No & t-value & p-value \\
\hline $\begin{array}{l}\text { Company } \\
\text { Information }\end{array}$ & 93 & $167^{*}$ & 17 & 1.0 & .29 \\
\hline $\begin{array}{l}\text { Product } \\
\text { Information }\end{array}$ & 91 & 164 & 65 & 0.75 & .46 \\
\hline $\begin{array}{l}\text { Hyperlinks to } \\
\text { other Sites }\end{array}$ & 44 & 237 & 89 & 2.03 & .05 \\
\hline $\begin{array}{l}\text { Online sale s } \\
\text { transactions }\end{array}$ & 35 & 120 & 173 & 0.78 & .43 \\
\hline $\begin{array}{l}\text { Stock/Inventory } \\
\text { status }\end{array}$ & 17 & 171 & 153 & 0.20 & .84 \\
\hline Online Catalogue & 53 & 160 & 128 & 2.03 & .05 \\
\hline $\begin{array}{l}\text { Customer Service } \\
\text { Area }\end{array}$ & 54 & 155 & 157 & 0.97 & .74 \\
\hline $\begin{array}{l}\text { Other company } \\
\text { Advertisements }\end{array}$ & 29 & 129 & 168 & 0.59 & .56 \\
\hline $\begin{array}{l}\text { Company } \\
\text { Financial Data }\end{array}$ & 7 & 483 & 135 & 2.31 & .02 \\
\hline Reflec con & & & & \\
\hline
\end{tabular}

Reflects company size average in terms of employees.

Table 5. Relationships between Company Size and Web-site Contents

\section{DISCUSSION AND CONCLUSIONS}

Ninety-four SMEs from a region in the Northeastern United States were surveyed in order to profile their Internet and EC practices. The majority of the responding firms have started recently to use the Internet for one reason or another. Most of the businesses surveyed use the Internet to provide information about their products and services. However, on average, approximately 6 percent of the surveyed firms' sales are attributed to EC. Further, only one from every four firms utilize the Internet regularly in conducting business (e.g., promotion, sales, 
purchases, customer service, and gathering online marketing, vendor and distributor data).

The results suggest some relationships of a firm's sales and profitability on one hand and the firm's Internet use on the other hand. Firms that rated their profitability and sales levels to be higher seem to have higher use of the Internet to gather distributor and vendor information, to conduct online purchasing, and to promote their products online. The majority of the firms surveyed tend to use e-mail to a great extent for communications internally among employees and externally with customers, vendors and distributors. In addition, higher levels of e-mail usage for internal and external communications tend to associate with higher levels of reported sales and profitability. Finally, larger firms tend to have online financial data, online catalog, and their we-sites tend to have more links to other sites.

A more advanced use of the Internet requires more managerial and technical resources. Since larger firms are expected to be more resourceful, compared to the smaller ones, a firm's size may influence the breadth and depth of its Internet use. Fore example, the findings of this investigation suggest that that most of the surveyed SMEs do not employ the Internet to its full capacity. Many still think EC is just having a web page. But EC is much more than that. A firm engaging in EC must create a business infrastructure to go with it. Also, EC requires substantial infrastructure planning with the intention of avoiding putting together an EC site in a few weeks on underpowered hardware equipped with narrow pipes, ill considered software and no data management strategy.

SMEs are hindered by the inadequate investment in skills and technologies, compared to large companies. Other issues include security, cost, and resistance (Davis \& Garcia-Sierra, 1999). Successful application requires positive attitudes towards information technology and the ability to identify and solve the problems that possibly accompany EC. SMEs need to understand the development of web presence sites is becoming a competitive necessity, particularly the need to establish online storefront.

Finally, SMEs also need to know the barriers to entry; the difficulty in establishing a market leadership position, and the cost of entry will increase in direct proportion to the delay in investing in web technology and EC applications (O'Shea, 1999). To get to this point, SMEs need to keep in mind the need for developing their own EC strategies. They need to focus on EC infrastructure, strong partnerships and the core products and structure in order to ensure that online business will be effectively conducted in the digital economy era.

\section{REFERENCES}

Aaron, R., Decina, M., and Skillen, R. (1999), Electronic commerce: Enablers and implications, IEEE Communications Magazine, September, pp. 4752.

Davies, A.J. and Garcia-Sierra, A.J., (1999), Implementing electronic commerce in SMEsthree case studies, BT Technology Journal, Vol 17, No. 3, pp. 97-111. 
Garrett, S.G.E., Skevington, P.J., (1999), An introduction to eCommerce, BT Technology Journal, Vol. 17, No. 3, pp. 11-16.

Hof, Robert (1999), "Is that E-Commerce Roadkill I see?"Business Week, (September 27), EB 96.

Levis, K., (1996), Electronic Commerce, British Telecommunications Engineering, Vol. 14, No. 4, pp. 281-285.

McCarthy, J.C., 91999), The social impact of electronic commerce, IEEE Communications Magazine, September, pp. 53-57.

Moeller, Michael (1999), "A Hidden Goldmine Called Inktomi," Business Week, (September 27), EB 72-73.

Morphett, I., 1999, Foreword, BT Technology Journal, Vol. 17, No. 3.

O’Shea, E., (1999), IEEE Communications Magazine, September, pp. 83-86.

Quelch, J.A., and Klein, L.R., (1996), The Internet and international marketing, Sloan Management Review, Spring, pp. 60-75.

Rhodes, R., and Carter, R., (1998), Electronic commerce technologies and changing product distribution, Int. J. Technology Management, Vol. 15, Nos 1-2, pp. 31-48. 